\title{
Thanatophoric dysplasia: a case report
}

\section{Uruj Jahan, Astha Sharma*, Neena Gupta, Shruti Gupta, Fatima Usmani, Ankita Rajput}

Department of Obstetrics and Gynaecology, G. S. V. M. Medical College, Kanpur, Uttar Pradesh, India

Received: 08 November 2018

Accepted: 13 December 2018

\section{*Correspondence:}

Dr. Astha Sharma,

E-mail: dr.sharmaastha@gmail.com

Copyright: (c) the author(s), publisher and licensee Medip Academy. This is an open-access article distributed under the terms of the Creative Commons Attribution Non-Commercial License, which permits unrestricted non-commercial use, distribution, and reproduction in any medium, provided the original work is properly cited.

\section{ABSTRACT}

Thanatophoric Dysplasia (TD) is a congenital, sporadic and most lethal skeletal dysplasia caused by new mutation in FGFR3 gene. Authors report such a rare case of a term alive baby with dysmorphic features, born to an unbooked, 40 years old $\mathrm{G}_{4} \mathrm{P}_{3+0}$ with non-consanguineous marriage; admitted at 9 months of gestation to present hospital with complain of pain abdomen for 2 days. Patient delivered a term female baby of vaginally which had delayed cry after birth, Admitted in NICU immediately with respiratory distress. The baby looked dysmorphic and suggested TD as most likely diagnosis. The case is being reported for its rarity and for high importance of early booking and anomaly scan. Early diagnosis is important since it provides alternative options of termination of pregnancy when an affected foetus is detected.

Keywords: Dysmorphic features, Non-consanguinous, Thanatophoric dysplasia

\section{INTRODUCTION}

Thanatophoric Dysplasia (TD) is a congenital, sporadic and usually lethal skeletal dysplasia. Its incidence is 1 in 20000 to 50000 of live births. At birth it is characterized by micromyelia, small conical thorax, platyspondyly (flat vertebral bodies) and macrocephaly. ${ }^{1}$ It is caused by denovo autosomal mutation in the fibroblast growth factor receptor 3 (FGFR3) gene located on chromosome 4 p16.3. ${ }^{2}$ It has 2 subtypes and TD type I, being the most common subtype. The two subtypes can be differentiated by the skull shape and femur morphology. TD type I, the most common subtype, characterized by curved and short femur which is in a telephone receiver like configuration and no cloverleaf shaped skull. Also, the abdomen appears protuberant in comparison with the chest which is narrow and small. The fetuses with type II TD are reported to have cloverleaf skull which means a trilobed skull. The premature closure of coronal and lambdoid sutures is commonly seen with the cloverleaf skull. ${ }^{3}$ Other features common to both TD include small narrow thorax with horizontally placed short ribs, macrocephaly, large anterior fontanel, a small foramen magnum, distinctive facial features (frontal bossing, low nasal bridge, flat faces), severe platyspondyly, marked shortening and bowing of long bones, brachydactyly (short broad tubular bones in hands and feet), redundant skin folds along the limbs etc. Authors report one such rare case of an unbooked patient after delivery.

\section{CASE REPORT}

An unbooked 40 years old female; $\mathrm{G}_{4} \mathrm{P}_{3+0}$ with nonconsanguineous marriage, with prior no antenatal visits; admitted to present hospital at full term in second stage of labour. There was no history of fever, rashes, spotting per vaginum, any drug intake, radiation exposure, family h/o congenital anomalous baby. She was not addicted to smoking, alcohol or any drug abuse. There was no past and family history of congenital abnormalities, diabetes mellitus, hypertension and thyroid dysfunction. 


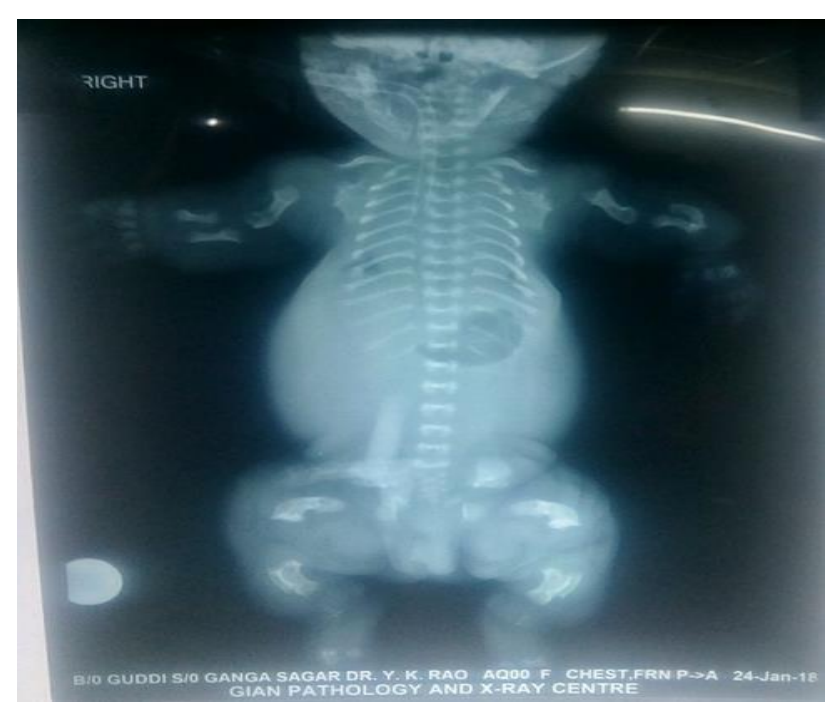

Figure 1: Infantogram.

At the time of admission her vitals were within normal limits. There was mild pallorand oedema. There was no thyroid swelling or any significant lymphadenopathy. No abnormality detected on respiratory, CVS or CNS examination. P/A fundal height was 36 weeks with fetus in longitudinal lie, cephalic presentation fetal heart rate was $120 / \mathrm{min}$ with good uterine contraction. On P/V os fully dilated, cervix fully effaced, membranes absent and head at 0 station. Herroutine blood investigationscomplete blood count, blood sugar, blood group, S.TSH were within normal limits. HIV, HBSAG, HCV, VDRL were non-reactive. Patient delivered a term female baby vaginally which had delayed cry after birth, admitted in NICU immediately with respiratory distress, intubated and expired after 12 hours. Baby looks was dysmorphic, had macrocephaly with HC $42 \mathrm{~cm}$. Face was coarse and edematous with frontal bossing, mid facial hypoplasia, depressed nasal bridge and short neck.

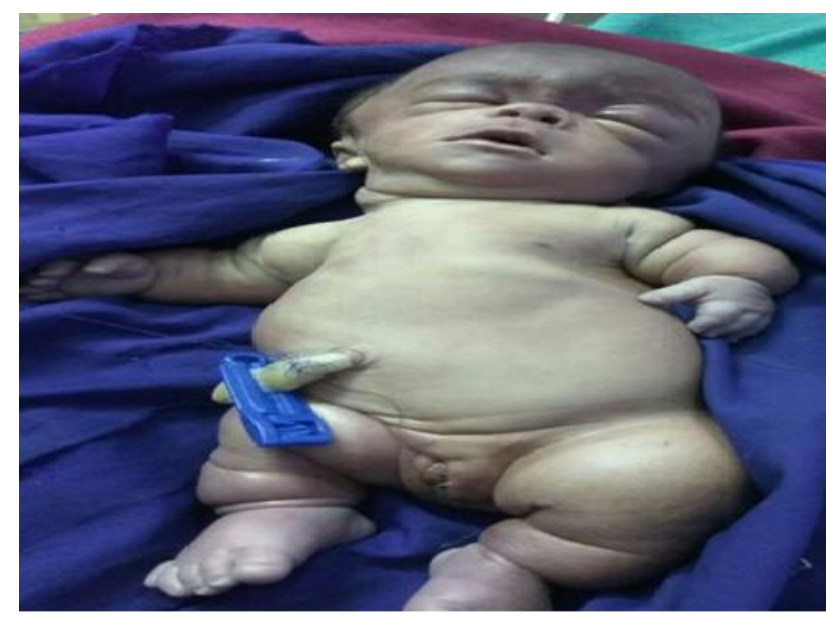

Figure 2: Newborn with features suggestive of type 1 thanotrophic dysplasia.

Upper and lower limbs were shortened with short stubby fingers and deep skin creases. Thorax was narrow, but abdomen was protuberant. Infant gram was done which showed following features small proximal portion of long limbs giving a rhizomelic appearance, markedly curved femur showing characteristic appearance "telephone receiver" with metaphyseal flaring, hypoplastic Iliac bones with small squared iliac wings, narrow chest with short horizontal ribs, macrocephaly, frontal bossing, nasal bridge flattening, platyspondyly. With above facial feature and skeletal abnormalities the diagnosis of TD type 1 was made.

\section{DISCUSSION}

The term thanotrophoric is derived from Greek word thanotopherus which means death bringing. This term was first described and used by Marotux for dwarf babies who died in 1st hour of life. Its incidence is 1 in 20000 to 50000 of live births. ${ }^{4}$ There are two subtypes with relative incidence: Type I-80\% and Type II-20\%. The two subtypes can be differentiated by the skull shape and femur morphology. 5

TD type I, the most common subtype, characterized by curved and short femur which is in a telephone receiver like configuration and no cloverleaf shaped skull. Also, the abdomen appears protuberant in comparison with the chest which is narrow and small. ${ }^{6}$

The fetuses with type II TD are reported to have cloverleaf skull which means a trilobed skull. The premature closure of coronal and lambdoid sutures is commonly seen with the cloverleaf skull.

Other features common to both TD include small narrow thorax with horizontally placed short ribs, macrocephaly, large anterior fontanel, a small foramen magnum, distinctive facial features (frontal bossing, low nasal bridge, flat faces), severe platyspondyly, marked shortening and bowing of long bones, brachydactyly (short broad tubular bones in hands and feet), redundant skin folds along the limbs etc.

Affected individuals could not survive so disorder never passes to the next generation. Most of the fetuses with TD die In-utero.

The cause of death is due to respiratory insufficiency which may be secondary to the narrow chest cavity and hypoplastic lungs, brainstem compression by the narrow foramen magnum or a combination of both. Surviving neonate is almost always ventilatory dependent as occurred in present case.

Diagnosis is confirmed after autopsy by histopathology which shows disorganized chondrocyte columns, poor cellular proliferation, lateral overgrowth of metaphysis and increased vascularity of cartilages but unfortunately could not be done in present case as consent was not given by the parents. 


\section{Diagnostic tool}

Although identification of a lethal skeletal dysplasia in the second trimester is often straight forward but establishing its specific diagnosis can be difficult. A three-dimensional ultrasound has an important role and description of external fetal morphology, the structure of fetal bones and the cranial sutures aids in the diagnosis of TD. Polyhydramnios in second and third trimester is common in both types. Occasional findings on both types are thickening of nuchal translucency in the 1st trimester, ventriculomegaly, agenesis of corpus callosum, cardiac defects and hydronephrosis. Prenatal diagnosis can be confirmed by molecular analysis of the mutation in FGFR3 gene extracted from fetal cells obtained by amniocentesis usually performed at 15-18 weeks of gestation or chronic villous sampling at about 10-12 weeks gestation.

Table 1: Review of cases of thanatophoric dysplasia reported earlier in literature from india.

\begin{tabular}{|c|c|c|c|}
\hline Author's name & $\begin{array}{l}\text { Age of baby/ } \\
\text { weight of baby }\end{array}$ & Diagnostic modalities & Outcome \\
\hline Tirumalasetti $\mathrm{N}^{5}$ & 26 weeks $/ 780 \mathrm{~g}$ & $\begin{array}{l}\text { Sonogram, radiograph and } \\
\text { clinical features }\end{array}$ & Stillborn \\
\hline Phatak SV et $\mathrm{al}^{7}$ & 30 weeks & Radiograph and clinical features & Stillborn \\
\hline Naveen NS et $\mathrm{al}^{8}$ & 22 weeks & Sonogram and clinical features & Dead fetus \\
\hline Lingappa $\mathrm{HA}$ et $\mathrm{al}^{9}$ & 28 weeks $/ 1.3 \mathrm{~kg}$ & $\begin{array}{l}\text { Clinical features } \\
\text { and autopsy }\end{array}$ & Stillborn \\
\hline Devangeri $\mathrm{RS}^{10}$ & 20 weeks $/ 400 \mathrm{~g}$ & $\begin{array}{l}\text { Clinical features, } \\
\text { radiograph and autopsy }\end{array}$ & Stillborn \\
\hline Gopal G et al ${ }^{11}$ & 34 weeks $/ 2.1 \mathrm{~kg}$ & $\begin{array}{l}\text { Clinical features, radiograph } \\
\text { and autopsy }\end{array}$ & $\begin{array}{l}\text { Live birth died } 24 \text { hours after } \\
\text { birth }\end{array}$ \\
\hline Kocherla $\mathrm{K}$ et al ${ }^{12}$ & 26 weeks & $\begin{array}{l}\text { Sonogram, radiograph } \\
\text { and clinical features }\end{array}$ & Dead fetus \\
\hline Sharma D et $\mathrm{al}^{13}$ & 37 weeks 4 days & Clinical features & Still born \\
\hline Hegade VP et al ${ }^{14}$ & 30 weeks & $\begin{array}{l}\text { Clinical features, } \\
\text { radiograph, CT Scan and autopsy }\end{array}$ & Still born \\
\hline Maratad DM et al ${ }^{15}$ & 17 weeks & $\begin{array}{l}\text { Sonogram, radiograph } \\
\text { and clinical features }\end{array}$ & MTP \\
\hline Durga $R$ et al ${ }^{16}$ & 26 weeks & $\begin{array}{l}\text { Sonogram, radiograph } \\
\text { and clinical features }\end{array}$ & MTP \\
\hline Yuvraj MF et al ${ }^{17}$ & 26 weeks $/ 600 \mathrm{~g}$ & $\begin{array}{l}\text { Sonogram } \\
\text { and clinical features }\end{array}$ & MTP \\
\hline
\end{tabular}

\section{CONCLUSION}

This case is being reported for its rarity and for high importance of early booking and anomaly scan. Good quality antenatal sonography can detect foetuses with features of TD in utero and further confirmation can be obtained by genetic sequencing and mutation analysis of FGFR3 gene. Early diagnosis of TD is important since it gives alternative options of termination of pregnancy when an affected foetus is detected.

Funding: No funding sources Conflict of interest: None declared

Ethical approval: Not required

\section{REFERENCES}

1. Maroteaux P, Lamy M, Robert JM. Thanatophoric dwarfism. La Presse Medicale. 1967;75(49):2519-24.
2. Noe EJ, Yoo HW, Kim KN, Lee SY. A case of thanatophoric dysplasia type I with an R248C mutation in the FGFR3 gene. Korean J Pediatr. 2010;53:1022-5.

3. Brodie SG, Kitoh H, Lipson M, Sifry-Platt M, Wilcox WR. Thanatophoric dysplasia type I with syndactyly. Am Medical Genetics. 1998;80(3):260-2.

4. Wilcox WR, Tavormina PL, Krakow D, Kitoh H, Lachman RS, Wasmuth JJ, et al. Molecular, radiologic, and histopathologic correlations in thanatophoric dysplasia. Am J Med Genetics. 1998;78(3):274-81.

5. Tirumalasetti N. Case report of Thanatophoric dysplasia: A lethal skeletal dysplasia. J NTR Univ Health Sci. 2013;2:275-7.

6. Chen CP, Chern SR, Stuh JC, Wang W, Yeh LF, Chang TY, et al. Prenatal diagnosis and genetic analysis of type 1 and 2 Thanatophoric dysplasia. Prenat Diag. 2001;21:89-95. 
7. Phatak SV, Pandit MP, Phatak MS, Kashikar R. Antenatal sonography diagnosis of thanatophoric dysplasia: A case report. Indian J Radiol Imaging. 2004;14(2):161-63.

8. Naveen NS, Murlimanju BV, Kumar V, Pulakunta T. Thanatophoric dysplasia: a rare entity. Oman Med J. 2011;26(3):196.

9. Lingappa HA, Karra S, Aditya A, Batra N, Chamarthy NP, Ravi Chander KWD. Autopsy diagnosis of thanatophoric dysplasia. J Indian Acad Forensic Med. 2013;35(3):296-98.

10. Davanageri RS, Shokeen PD, Bannur HB, Patil KP. Thanatophoric dysplasia type I: A rare case report at fetal autopsy. J Lab Physic. 2014;6(2):121.

11. Gopal G, Belavadi GB. Thanatophoric Dysplasia in newborn. J Evolution Med Dental Scienc. 2014;3(14):3665-9.

12. Kocherla K, Kocherla V. Antenatal diagnosis of thanatophoric dysplasia: a case report and review of literature. Int J Res Med Sci. 2014;2:1176-9.
13. Sharma D, Sharma CM. Thanatophoric dysplasia type 1 (TD1): a case report. Int J Reprod Contracept Obstet Gynecol. 2014;3:1127-9.

14. Hegade VP, Nagendra K, Pradeep N, Rudrappa S. Thanatophoric dwarfism. Int J Contemp Pediatr. 2015;2:238-42.

15. Maratad DM, Kuntoji NG. Thanatophoric DysplasiaA case report. Medica Innovatica. 2016;5(2):4.

16. Durga R, Devi RTK. A rare case of thanatophoric dysplasia. Am J Med Case Reports. 2016;4(1):35-7.

17. Yuvaraj MF, Sankaran PK, Raghunath G, Begum Z, Kumaresan KM. Thanatophoric dysplasia; a rare case report on a congenital anomaly. Int J Pediatr. 2017;5(1):4227-31.

Cite this article as: Jahan U, Sharma A, Gupta N, Gupta S, Usmani F, Rajput A. Thanatophoric dysplasia: a case report. Int J Reprod Contracept Obstet Gynecol 2019;8:758-61. 